\title{
Heat-treated milk differentiation by a sensitive lactulose assay
}

\author{
Emanuele Marconia,*, Maria Cristina Messia ${ }^{\mathrm{a}}$, Azize Amine ${ }^{\mathrm{b}}$, Danila Moscone ${ }^{\mathrm{c}}$, \\ Francesco Vernazza $^{\mathrm{d}}$, Francesco Stocchi ${ }^{\mathrm{d}}$, Giuseppe Palleschi ${ }^{\mathrm{c}}$ \\ ${ }^{a}$ DISTAAM, Università del Molise, Via De Sanctis-86100, Campobasso, Italy \\ ${ }^{\mathrm{b}}$ Faculté des Sciences et Techniques de Mohammadia, Morocco \\ 'Dipartimento di Scienze e Tecnologie Chimiche, Università di Roma "Tor Vergata", Italy \\ ${ }^{d}$ Parmalat, Ricerca e Sviluppo, Sala Baganza, Parma, Italy
}

Received 7 March 2003; received in revised form 15 May 2003; accepted 15 May 2003

\begin{abstract}
A sensitive enzymatic assay for determining lactulose (detection limit $=2.5 \mathrm{mg} / \mathrm{l} ; \mathrm{RSD}<4 \%$ ) was applied to 90 samples of various milk categories, such as, pasteurized milk (fresh and high-temperature), UHT milk (indirect, direct, by infusion and by injection), and in-container sterilized milks. Results showed that it was possible to distinguish, by lactulose content, not only incontainer sterilized milk (744 mg/l), indirect UHT $(341 \mathrm{mg} / \mathrm{l})$ and direct UHT $(165 \mathrm{mg} / \mathrm{l})$, but also UHT milk produced by mild technologies such as milk treated by infusion $(107 \mathrm{mg} / \mathrm{l})$, high-temperature pasteurized milk $(58 \mathrm{mg} / \mathrm{l})$, and low temperature pasteurized milk $(3.5 \mathrm{mg} / \mathrm{l})$.
\end{abstract}

(C) 2003 Elsevier Ltd. All rights reserved.

Keywords: Lactulose; Pasteurized and sterilized milks; Enzymatic assay; Heat damage; Process identification

\section{Introduction}

Continuous developments in the heat treatment processes of milk and in alternative procedures, such as microfiltration (Larsen, 1996), have given rise to a number of commercial milks, such as pasteurized (low and high-temperature), microfiltered and pasteurized/ UHT, UHT (direct and indirect systems), and in-container sterilized milk. The establishment of thermal parameters, defined under specific temperature/time conditions, contributes to the classification of heattreated milks. These thermal parameters are mainly employed to identify and optimize processes, assess heat-loads and identify the degree of thermal damage (Glaeser, 1996; Morales, Romero, \& Jimenez-Perez, 2000; Pellegrino, Resmini, \& Luf, 1994).

Lactulose was proposed by the International Dairy Federation and the European Union as a parameter

\footnotetext{
* Corresponding author. Tel.: +39-0874-404616; fax: +39-0874404652.

E-mail address: marconi@unimol.it (E. Marconi).
}

capable of differentiating between UHT milk and incontainer sterilized milk (EU Commission, 1992; IDF, 1992, 1993). Both international bodies suggested 600 $\mathrm{mg} / \mathrm{l}$ of lactulose as a marker for distinguishing between the two milk types, so as to guarantee the quality of UHT milk.

With regard to pasteurized, microfiltered and pasteurized, high temperature pasteurized milk and reconstituted powdered milk, upper limits (threshold) of lactulose concentrations cannot be proposed since the methods available for lactulose determination are neither sufficiently sensitive (level of detection $50 \mathrm{mg} / \mathrm{l}$ ) (Andrews, 1986; De Block, Merchieres, Van Renterghem, \& Moermans, 1996; Olano, Calvo, \& Corzo, 1994), nor routinely applicable (Andrews, 1986; Boehringer Mannheim, 1995; Mayer, Genrich, Kunnecke, \& Bilitewski, 1996; Moscone, Bernardo, Marconi, Amine, \& Palleschi, 1999).

In this study, a robust enzymatic-spectrophotometric method, that we had previously developed (Amine, Moscone, Bernardo, Marconi, \& Palleschi, 2000), was adapted to improve its sensitivity and validated at low and very low lactulose concentrations. In particular, this 
method was applied to milks of different heat-processes, such as fresh pasteurized milk, high-temperature pasteurized milk, direct UHT milk treated by both injection and infusion systems, indirect UHT-treated milk, and in-container sterilized milk, in order to distinguish the heat treatments used.

\section{Materials and methods}

\subsection{Samples}

The samples included fresh pasteurised (PAST) milk $(n=10)$, high-temperature pasteurized (HT PAST) milk $(n=10)$, direct UHT-treated milk using an injection system (INJ UHT) $(n=20)$, direct UHT-treated milk using an infusion system (INF UHT) $(n=20)$, indirect UHT-treated milk using a plate or a tubular heatexchange system (IND UHT) $(n=20)$, and in-container sterilized (STER) milk $(n=10)$.

The sterilized milk samples (UHT and STER) were produced at the production plant and at the pilot plant of the Dairy Research and Development Centre of Parmalat, Sala Baganza, Parma, Italy. Pasteurized milk samples (PAST and HT PAST) were purchased at supermarkets in Rome and Parma (Italy).

\subsection{Lactulose analysis}

\subsubsection{General}

The lactulose analysis was performed by adapting the enzymatic-spectrophotometric assay standardized by Amine et al. (2000) to improve its sensitivity. The method is based on the assumption that free fructose is absent in milk but derives from lactulose hydrolysis. Lactulose is hydrolysed to D-galactose and D-fructose with $\beta$-galactosidase. The liberated $D$-fructose is equivalent to the amount of lactulose. In the presence of the fructose dehydrogenase (FDH) and the electron carrier phenazine methosulfate (PMS), fructose and 3(4,5-dimethylthiazol-2yl)-2,5-diphenyltetrazolium bromide (MTT) produce a coloured compound (MTT Formazan), measured by its light absorbance at 570 nm.

\subsubsection{Sample treatment}

A milk sample of $10 \mathrm{ml}$ was pipetted into a $50 \mathrm{ml}$ conical flask and $1.75 \mathrm{ml}$ of both Carrez I and II were gradually added successively; the resulting solution was stirred for 2-3 min, then $6.5 \mathrm{ml}$ of citric/phosphate buffer was added. The solution was then thoroughly mixed for 2-3 min, left to rest for $30 \mathrm{~min}$ and filtered through a filter paper eliminating the first $2-3 \mathrm{ml}$ of filtrate. $1 \mathrm{ml}$ of milk filtrate, $0.2 \mathrm{ml}$ of $\beta$-galactosidase and $0.3 \mathrm{ml}$ of citric/phosphate buffer were added in succession to each glass-stoppered test tube $(7.5 \times 1.0 \mathrm{~cm})$. The test tubes were placed in a water bath at $65 \pm 0.1{ }^{\circ} \mathrm{C}$ for $12 \mathrm{~min}$ then cooled in tap water.

\subsubsection{Absorbance measurement}

One-hundred microlitres of MTT, $50 \mu \mathrm{l}$ of PMS, milk hydrolysate $(200 \mu \mathrm{l}$ for STER/UHT milk and $500 \mu \mathrm{l}$ for HT PAST/PAST milk) and citric/phosphate buffer were mixed in a $1 \mathrm{~cm}$ light path cuvette. The reaction started with 2 units $(16 \mu l)$ of FDH for STER/UHT/HT PAST milk and 6 units $(48 \mu \mathrm{l})$ of FDH for PAST milk. The volume of the buffer was modulated to maintain the final volume at $1.0 \mathrm{ml}$. The increase in absorbance at 570 nm was measured after $12 \mathrm{~min}$ at room temperature.

A blank was prepared for each milk sample, using the same procedure as the above, without adding the FDH solution.

\subsection{Reagents}

These were, fructose dehydrogenase (FDH) (EC 1.1.99.11, 112 units mg/solid) (Sigma Chemical Co., St. Louis, MO, 63178, USA) and $\beta$-D-galactosidase from Aspergillus orizae (EC 3.2.1.23, 9 units $\mathrm{mg} / \mathrm{solid}$ ) (Sigma).

All other chemicals, of high purity, were purchased from Sigma (St. Louis, MO, USA).

\subsection{Apparatus}

Absorbance measurements were made with a Varian DMS UV-visible spectrophotometer (Varian Inc., Walnut Creek, CA, 94598, USA) using a $1 \mathrm{~cm}$ cuvette light path.

\section{Results and discussion}

The analytical performances of the enzymatic assay were tested at low and very low concentrations of lactulose. Two calibration curves were plotted by adding varying amounts of lactulose standard to PAST milk (from 2.5 to $20 \mathrm{mg} / 1$ using $6 \mathrm{FDH}$ units and $500 \mu \mathrm{l}$ of hydrolysate volume, and from 10 to $100 \mathrm{mg} / 1 \mathrm{using} 2$ FDH units and $500 \mu \mathrm{l}$ of hydrolysate volume). The standard curves were linear and described by the equations $y=0.0061 x, \quad R^{2}=0.988, \quad P \leqslant 0.001 \quad$ and $y=0.0118 x+0.0135, R^{2}=0.999, P \leqslant 0.001$, for 6 and 2 FDH units, respectively.

Excellent precision $(n=6)$ was confirmed at low lactulose concentration, since the absorbance RSDs were 3.0 and $3.7 \%$ for PAST and HT PAST milk, respectively.

The accuracy of this system was checked by running a recovery test after the addition of increasing amounts of lactulose (from 2.5 to $20 \mathrm{mg} / 1$ ) to PAST milk (Table 1). The results of the recovery test were satisfactory, with values ranging from 101 to $105 \%$. 
Table 1

Recovery test of different amounts of lactulose added to fresh pasteurized milk

\begin{tabular}{lcll}
\hline Lactulose added $(\mathrm{mg} / \mathrm{l})$ & $\begin{array}{l}\text { Lactulose } \\
\text { recovered }(\mathrm{mg} / \mathrm{l})\end{array}$ & $\begin{array}{l}\text { Recovery } \\
(\%)\end{array}$ & $\begin{array}{l}\text { RSD } \\
(n=3)\end{array}$ \\
\hline 2.5 & 2.56 & 102 & 2.9 \\
5.0 & 5.11 & 103 & 3.5 \\
7.5 & 7.55 & 101 & 2.7 \\
10.0 & 10.27 & 103 & 3.2 \\
15.0 & 15.41 & 103 & 2.1 \\
20.0 & 21.03 & 105 & 3.1 \\
\hline
\end{tabular}

The detection limit of lactulose in milk samples was significantly improved up to $2.5 \mathrm{mg} / 1$ using $6 \mathrm{FDH}$ units and $500 \mu \mathrm{l}$ of hydrolysate. This was significantly lower than those of any of the available methods varying from $10 \mathrm{mg} / \mathrm{l}$ of the enzymatic-spectrophotometric method to $200 \mathrm{mg} / 1$ of the HPLC reference method (Andrews, 1986; Boehringer Mannheim, 1995; Cataldi, Angelotti, \& Bufo, 1999; De Block et al., 1996; De Rafael, Calvo, \& Olano, 1996; IDF, 1998; Martinez-Castro \& Olano, 1981; Moscone et al., 1999; Olano et al., 1994). The above detection limit is sufficiently low to allow the quantification of lactulose in all types of heat-treated milks, from low pasteurized to in-container sterilized milks.

The present method for the quantification of lactulose in milk samples, besides being significantly more sensitive, is also more rapid than those routinary used (Boehringer Mannheim, 1995; IDF, 1998; Olano et al., 1994). The complete time of analysis (deproteinization +analysis) is $60 \mathrm{~min}$ for one sample and $100 \mathrm{~min}$ for 20 samples.

In order to verify the use of lactulose as a process indicator for pasteurized and direct UHT milks, 90 milk samples of different heat-classes were analysed. The lactulose values of the pasteurised (PAST and HT PAST), direct UHT (INF UHT and INJ UHT), indirect UHT (IND UHT) and in-container sterilized (STER) milks are given in Fig. 1.

The lactulose content of STER milk varied from 493 to $1147 \mathrm{mg} / 1$, with an average value of $744 \mathrm{mg} / \mathrm{l}$, which was significantly higher than any of the UHT milks (max lactulose content $421 \mathrm{mg} / 1$ in IND UHT sample). The limit of $600 \mathrm{mg} / 1$ proposed by the European Union could be lowered to $400 \mathrm{mg} / 1$ to protect the quality of UHT milk from excessive heat-load, as adopted by Germany (Pellegrino, De Noni, \& Resmini, 1995). Since the method is highly sensitive, lactulose formation can be monitored in pasteurized milk and in UHT milk produced by gentle technologies, such as the infusion system.

The lactulose content of HT PAST milk, varies from 32 to $79 \mathrm{mg} / \mathrm{l}$, with an average of $58 \mathrm{mg} / \mathrm{l}$. This enables differentiation from both PAST milk (range $2-6 \mathrm{mg} / \mathrm{l}$;

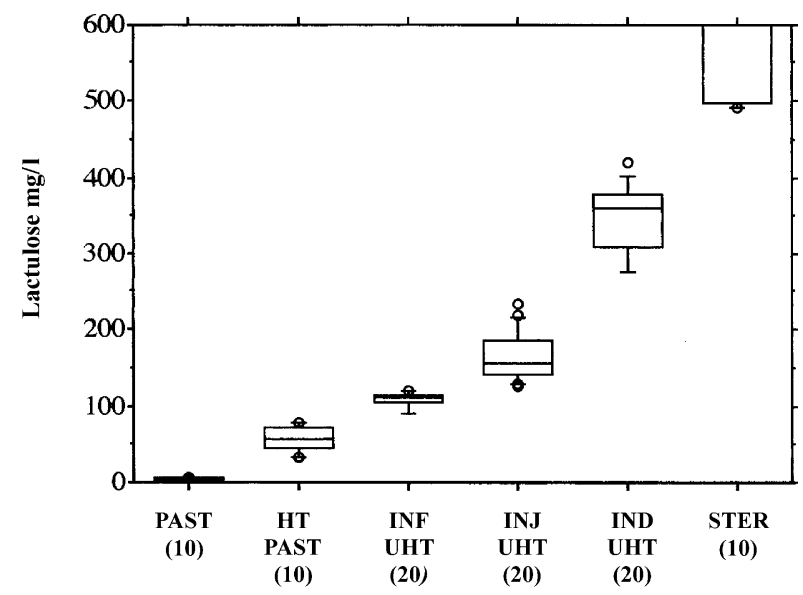

Fig. 1. Box and whisker plots of lactulose contents in milks of different heat-processes: PAST $=$ fresh pasteurized milk; HT PAST $=$ hightemperature pasteurized milk; IND UHT=indirect UHT-treated milk; INJ UHT = direct UHT-treated milk using an injection system; INF UHT = direct UHT-treated milk using an infusion system; STER $=$ In-container sterilized milk. () Number of samples per class. The central box covers the middle $50 \%$ of the data values, between the lower and upper percentiles. The whiskers extend out from the 10th and 90th percentiles. The central line is at the median. When unusual values occur for away from the bulk of the data, they are plotted as separate points.

average $3.5 \mathrm{mg} / \mathrm{l}$ ) and UHT milks such as INJ UHT (range $126-233 \mathrm{mg} / \mathrm{l}$; average $165 \mathrm{mg} / \mathrm{l}$ ) or IND UHT (range 275-421 mg/l; average $348 \mathrm{mg} / \mathrm{l}$ ). The lactulose content of INF UHT milk (range $89-120 \mathrm{mg} / \mathrm{l}$; average $107 \mathrm{mg} / \mathrm{l}$ ) is between those of INJ UHT and HT PAST milk, which confirms that this sterilization process reduces thermal damage to raw milk, thus protecting its physicochemical, nutritional and organoleptic properties (de Jong, Waalewijn, \& Van der Linden, 1996).

Having a sensitive analytical method available means that a maximum limit (threshold) for lactulose can be defined, not only to differentiate between UHT and sterilized milks, but also between and within different types of UHT and pasteurized milks.

Lactulose concentrations may be used in combination with other indices (furosine, $\beta$-lactoglobulin, soluble whey protein, BSA, $\alpha$-lactoalbumin, HMF, peroxidase and alkaline phosphatase) to differentiate, with greater certainty, between various types of pasteurized and sterilized milks and to assess the heat damage in reconstituted powdered milk, and in sterilized creams [Corzo, Delgado, Troyano, \& Olano, 1994; De Rafael et al., 1996; EU Commission, 1992; Glaeser, 1996; IDF, 1992; Morales et al., 2000; Pellegrino et al., 1994 (Chapter. 20), 1995; Van Renterghem \& De Block, 1996]. The method proposed in this study is simple, rapid, sensitive and meets the needs of both the quality control and milk processing laboratories, thus contributing to product quality assurance. Moreover, this method can be 
readily adapted to an enzymatic test kit, making it suitable for running a large number of analyses.

\section{References}

Amine, A., Moscone, D., Bernardo, R. A., Marconi, E., \& Palleschi, G. (2000). A new enzymatic spectrophotometric assay for the determination of lactulose in milk. Analytica Chimica Acta, 406, 217-224.

Andrews, G. R. (1986). Formation and occurrence of lactulose in heated milk. Journal of Dairy Research, 53, 665-680.

Boehringer Mannheim (1995). Lactulose in milk UV-method. In Methods of biochemical analysis and food analysis using test-combinations (pp. 92-93). Mannheim, Germany: Boehringer Mannheim $\mathrm{GmbH}$.

Cataldi, T. R. I., Angelotti, M., \& Bufo, S. A. (1999). Method development for the quantitative determination of lactulose in heat-treated milks by HPAEC with pulsed amperometric detection. Analytical Chemistry, 71, 4919-4925.

Corzo, N., Delgado, T., Troyano, E., \& Olano, A. (1994). Ratio of lactulose to furosine as indicator of quality of commercial milks. Journal of Food Protection, 57, 737-739.

De Block, J., Merchiers, M., Van Renterghem, R., \& Moermans, R. (1996). Evaluation of two methods for the determination of lactulose in milk. International Dairy Journal, 6, 217-222.

de Jong, R., Waalewijn, R., \& Van der Linden, H. J. L. J. (1996). Direct heating of milk by steam infusion. In Heat treatments and alternative methods (pp. 51-72) Brussels: International Dairy Federation.

De Rafael, D., Calvo, M. M., \& Olano, A. (1996). Determination of low levels of lactulose in milk. Milchwissenschaft, 51, 552-553.

EU Commission, Dairy Chemist's Group Doc. VI/5726/92. (1992). Rev. 2. Proposal of the Commission.

Glaeser, H. (1996). Alternative methods: legal and control aspects. In Heat treatments \& alternative methods (pp. 438-447). Brussels: International Dairy Federation.
IDF. (1998). Heat treated milk. Determination of lactulose content. Method using high-performance liquid chromatography. Standard 147B. Brussels: International Dairy Federation.

IDF. (1992). Influence of technology on the quality of heat treated milk and fluid milk products. (B-Doc. 222). Brussels: International Dairy Federation.

IDF. (1993). Influence of technology on the quality of heat treated milk and fluid milk products. (B-Doc. 235). Brussels: International Dairy Federation.

Larsen, P. H. (1996). Microfiltration for pasteurized milk. In: Heat treatments and alternative methods (pp. 232-239) Brussels: International Dairy Federation.

Martinez-Castro, I., \& Olano, A. (1981). Ready detection of small amounts of lactulose in dairy products by thin-layer chromatography. Chromatographia, 14, 621-622.

Mayer, M., Genrich, M., Kunnecke, W., \& Bilitewski, U. (1996). Automated determination of lactulose in milk using an enzyme reactor and flow analysis with integrated dialysis. Analytica Chimica Acta, 324, 37-45.

Morales, F.-J., Romero, C., \& Jimenez-Perez, S. (2000). Characterization of industrial processed milk by analysis of heat-induced changes. International Journal of Food Science and Technology, 35, 193-200.

Moscone, D., Bernardo, R. A., Marconi, E., Amine, A., \& Palleschi, G. (1999). Rapid determination of lactulose in milk by microdialysis and biosensors. Analyst, 124, 325-329.

Olano, A., Calvo, M. M., \& Corzo, N. (1994). Changes in the carbohydrate fraction of milk during heating processes. Food Chemistry, 31, 259-265.

Pellegrino, L., De Noni, I., \& Resmini, P. (1995). Coupling of lactulose and furosine: indices for quality evaluation of sterilized milk. International Dairy Journal, 5, 647-659.

Pellegrino, L., Resmini, P., \& Luf, W. (1994). Assessment (Indices) of heat treatment of milk. In Heat induced changes in milk (2nd ed., pp. 409-453) Brussels: International Dairy Federation.

Van Renterghem, R., \& De Block, J. (1996). Furosine in consumption milk and milk powders. International Dairy Journal, 6, 371-382. 